\title{
Gelatinous zooplankton net-collected in the Gulf of Maine and adjacent submarine canyons: new species, new family (Jeanbouilloniidae), taxonomic remarks and some parasites
}

\author{
FRANCESC PAGÈS ${ }^{1}$, PER FLOOD ${ }^{2}$ and MARSH YOUNGBLUTH ${ }^{3}$ \\ ${ }^{1}$ Institut de Ciències del Mar (CSIC), Passeig Marítim de la Barceloneta 37-49, 08003 Barcelona, Catalunya, Spain. \\ E-mail: fpages@icm.csic.es \\ ${ }^{2}$ Bathybiologica A/S, Bergen, Norway. E-mail: per.r.flood@bathybiologica.no \\ ${ }^{3}$ Harbor Branch Oceanographic Institution, Fort Pierce, Florida, USA. E-mail: youngbluth@ @boi.edu.
}

\begin{abstract}
SUMMARY: A systematic account is provided of the siphonophores, medusae, ctenophores, molluscs and salps net-collected in basins of the Gulf of Maine and adjacent canyons during three cruises carried out in September 2002, 2003 and 2004. We describe the siphonophore Lensia quadriculata sp. nov. and the hydroidomedusae Jeanbouillonia maserati gen. nov. et sp. nov., the latter is the first member of the new family Jeanbouilloniidae. New observations are made about the morphology and/or systematics of the siphonophore Gilia reticulata and the hydroidomedusae Bougainvillia platygaster, Bougainvillia principis, Modeeria rotunda, Clytia hemisphaerica, Orchistoma collapsum and Dichotomia cannoides. Parasites associated with the ctenophores Pleurobrachia pileus (a cestode) and Beroe sp. (a hyperid amphipod) are reported.
\end{abstract}

Keywords: gelatinous zooplankton, Gulf of Maine, new species, Jeanbouillonia, Lensia, Gilia, Bougainvillia, Modeeria, Dichotomia, Dipleurosoma.

RESUMEN: ZoOPLANCTON GELATINOSO RECOGIDO CON REDES EN EL GOLFO DE MAINE CON DESCRIPCIONES DE UN NUEVO SIFONÓFORO, UNA NUEVA ANTOMEDUSA Y DIAGNOSIS DE LA NUEVA FAMILIA JEANBOUILLONIIDAE. - Se presenta un directorio sistemático de los sifonóforos, medusas, ctenóforos, moluscos y salpas recogidos con redes en las cuencas del golfo de Maine y cañones submarinos adyacentes durante tres cruceros realizados en septiembre de 2002, 2003 y 2004. El sifonóforo Lensia quadriculata sp. nov. y la hidroidomedusa Jeanbouillonia maserati gen. nov. et sp. nov. son descritos, ésta última especie es el primer miembro de la nueva familia Jeanbouilloniidae. Se aportan nuevas observaciones sobre la morfología y/o posición sistemática del sifonóforo Gilia reticulata y de las hidroidomedusas Bougainvillia platygaster, Bougainvillia principis, Modeeria rotunda, Clytia hemisphaerica, Orchistoma collapsum y Dichotomia cannoides. Se registran algunos parásitos asociados a los ctenóforos Beroe sp. (un anfípodo hipérido) y Pleurobrachia pileus (un céstodo).

Palabras clave: zooplancton gelatinoso, golfo de Maine, especies nuevas, Jeanbouillonia, Lensia, Gilia, Bougainvillia, Modeeria, Dichotomia, Dipleurosoma.

\section{INTRODUCTION}

The epipelagic (0 to $200 \mathrm{~m}$ depth) and mesopelagic (200 to $1000 \mathrm{~m}$ depth) gelatinous zooplankton living in the Gulf of Maine and adjacent waters have mainly been researched in the second half of the XIX century (e.g. Agassiz, 1865; Fewkes, 1888 ) and the first half of the XX century (e.g. Mayer, 1912, Bigelow, 1914, 1926). Since then, oceanographic research has shifted towards more ecological studies, occasionally updating the gelatinous populations from in situ observations in sub- 
mersible dives (e.g. Larson et al., 1988). In September 2002, 2003 and 2004, three cruises were conducted in two basins (Wilkinson and Georges) of the Gulf of Maine and four adjacent submarine canyons (Oceanographer, Hydrographer, Atlantis and Lydonia) (north-western Atlantic) (Fig. 1) in order to explore the pelagic habitat and trophodynamics of the physonect siphonophore Nanomia cara using the manned submersibles Johnson-SeaLink. Zooplankton samples were collected between dives to complement the knowledge on the gelatinous populations living in the waters explored. The present study reports on all the species net-collected during the three cruises, describes two new cnidarian species and provides observations on the morphology and/or systematics of other little-known species.

\section{MATERIAL AND METHODS}

The specimens were captured either by a Meternet (200 $\mu \mathrm{m}$ mesh-size) hauled vertically and a multi-net Mocness (300 $\mu \mathrm{m}$ mesh-size) in the water column, and by a dipnet and a conical net (90 $\mu \mathrm{m}$ mesh-size) in surface waters. The Mocness equipped with nine nets was hauled either horizontally or obliquely at selected depths. Most of specimens were sorted with the naked-eye after recovering the nets and they were immediately examined and photographed under a binocular microscope or while drifting in a Planktonkreisel. Afterwards the samples were fixed in $4 \%$ buffered formaldehyde. Marked differences in the sampling occurred between cruises. For example, twenty Mocness hauls were conducted from near the seafloor to the sea surface among the three cruises, fifteen in 2002, four in 2003 and only one in 2004 after the winch broke. The six Meternet hauls were carried out in 2004. No attempt to make interannual variability analyses was made due to this random sampling.

\section{RESULTS}

Eighty-one species of gelatinous zooplankton were identified. In total, 33 were siphonophores, 28 hydroidomedusae, 8 scyphomedusae, 3 ctenophores, 6 molluscs and 3 salps (Table 1). One calycophoran

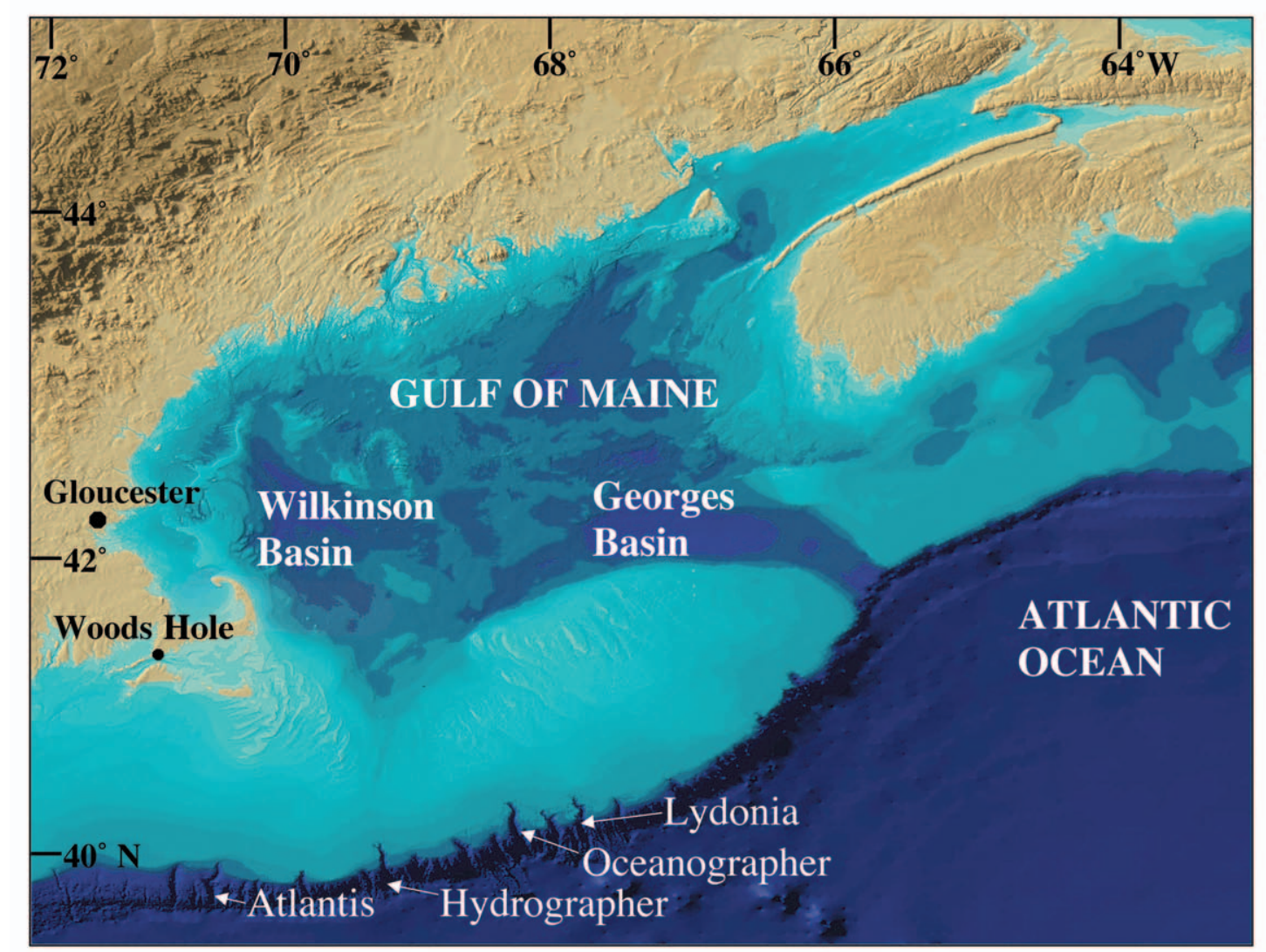

FIG. 1. - Map of the Gulf of Maine showing the basins and submarine canyons where zooplankton samples were collected. 
TABLE 1. - List of gelatinous species net-collected in the Gulf of Maine over the three cruises including those not mentioned in the main text.

\begin{tabular}{|c|c|c|c|c|}
\hline Taxa (species number) and species name & Location & Depth in metres (number of specimens) & Date & Remarks \\
\hline \multicolumn{5}{|l|}{ CNIDARIA } \\
\hline \multirow{3}{*}{$\begin{array}{l}\text { SIPHONOPHORAE (33) } \\
\text { Agalma elegans }\end{array}$} & Georges Basin & & & \\
\hline & Georges Basin & $35-7(1)$ & $11 / 9 / 03$ & \\
\hline & Oceanographer & $350-0(3)$ & $16 / 9 / 04$ & \\
\hline \multirow{2}{*}{ Agalma okeni } & Oceanographer & $500-375(1)$ & $23 / 9 / 03$ & \\
\hline & Atlantis & $600-0(1)$ & 21/9/04 & \\
\hline \multirow[t]{2}{*}{ Nanomia cara } & Georges Basin & $280-0(1)$ & $25 / 9 / 04$ & \\
\hline & Wilkinson Basin & $75-0(2)$ & $27 / 9 / 04$ & \\
\hline Cordagalma ordinata & Oceanographer & surface (1) & $15 / 9 / 04$ & \\
\hline \multirow{3}{*}{ Physophora hydrostatica } & Oceanographer & $225-150(1)$ & $2 / 9 / 02$ & \\
\hline & Oceanographer & $375-2(2)$ & $25 / 9 / 03$ & \\
\hline & Atlantis & $600-0(1)$ & $21 / 9 / 04$ & \\
\hline Amphycarion acaule & Oceanographer & $35-0(1)$ & $16 / 9 / 04$ & \\
\hline \multirow[t]{2}{*}{ Praya reticulata } & Hydrographer & $172-80(1)$ & $13 / 9 / 02$ & \\
\hline & Oceanographer & $500-375(1)$ & $23 / 9 / 03$ & \\
\hline Rosacea flaccida & Georges Basin & surface (1) & $13 / 9 / 03$ & \\
\hline \multirow[t]{2}{*}{ Desmophyes annectens } & Oceanographer & $350-0$ & $16 / 9 / 04$ & \\
\hline & Atlantis & $600-0(1)$ & $21 / 9 / 04$ & \\
\hline \multirow[t]{2}{*}{ Hippopodius hippopus } & Oceanographer & $350-0(1)$ & $16 / 9 / 04$ & \\
\hline & Oceanographer & $150-6(1)$ & 26/9/04 & \\
\hline Vogtia glabra & Atlantis & $501-464(1)$ & $16 / 9 / 02$ & \\
\hline Vogtia spinosa & Atlantis & $600-0(1)$ & 21/9/04 & \\
\hline \multirow{2}{*}{ Sulculeolaria quadrivalvis } & Oceanographer & $35-0(1)$ & $16 / 9 / 04$ & \\
\hline & Georges Basin & surface (1) & $24 / 9 / 04$ & \\
\hline \multirow{2}{*}{ Chelophyes appendiculata } & Oceanographer & $677-629(1)$ & 9/9/02 & \\
\hline & Oceanographer & surface waters & $15 / 9 / 04$ & \\
\hline Diphyes bojani & Oceanographer & surface waters & $15 / 9 / 04$ & \\
\hline \multirow{2}{*}{ Diphyes dispar } & Oceanographer & $350-0(2)$ & $16 / 9 / 04$ & \\
\hline & Oceanographer & $35-0(1)$ & $16 / 9 / 04$ & \\
\hline Dimophyes arctica & Hydrographer & $678-578(1)$ & $13 / 9 / 02$ & \\
\hline Lensia asymmetrica & Oceanographer & $777-678(1)$ & $9 / 9 / 02$ & \\
\hline \multirow[t]{2}{*}{ Lensia conoidea } & Oceanographer & $500-375(1)$ & $23 / 9 / 03$ & \\
\hline & Atlantis & $100-0(2)$ & 20/9/04 & \\
\hline Lensia meteori & Hydrographer & $678-578(1)$ & $13 / 9 / 02$ & \\
\hline & Atlantis & $100-0(2)$ & 20/9/04 & \\
\hline Lensia multicristata & Hydrographer & $678-578(2)$ & $13 / 9 / 02$ & \\
\hline Lensia quadriculata sp. nov. & & & & see text \\
\hline Gilia reticulata & & & & see text \\
\hline Crystallophyes amygdalina & Oceanographer & 777-678 (1) & 9/9/02 & \\
\hline Clausophyes ovata & Oceanographer & $777-678(1)$ & 9/9/02 & \\
\hline Chuniphyes moserae & Oceanographer & $777-678(1)$ & 9/9/02 & \\
\hline & Oceanographer & $661-600(1)$ & $16 / 9 / 04$ & \\
\hline Chuniphyes multidentata & Hydrographer & $678-578(1)$ & $13 / 9 / 02$ & \\
\hline Abylopsis eschscholtzi & Oceanographer & $35-0(1)$ & $16 / 9 / 04$ & \\
\hline Abylopsis tetragona & Oceanographer & $35-0(2)$ & $16 / 9 / 04$ & \\
\hline & Oceanographer & $350-0(1)$ & $16 / 9 / 04$ & \\
\hline Enneagonum hyalinum & Hydrographer & $317-278$ (1) & $17 / 9 / 02$ & \\
\hline Ceratocymba leuckarti & Oceanographer & $35-0$ ( 1 eudoxid $)$ & $16 / 9 / 04$ & \\
\hline Ceratocymba sagittata & Oceanographer & $0-661$ ( 1 eudoxid) & $16 / 9 / 04$ & \\
\hline Sphaeronectes gracilis & Atlantis & $100-0(2)$ & $20 / 9 / 04$ & \\
\hline ANTHOMEDUSAE (7) & & & & \\
\hline Bougainvillia principis & & & & see text \\
\hline Bougainvillia platygaster & & & & see text \\
\hline Leuckartiara octona & Georges Basin & on surface (3) & $13 / 9 / 03$ & Fig. 7F \\
\hline Leuckartiara sp. & Wilkinson Basin & $35-2(1)$ & $10 / 9 / 03$ & \\
\hline Cytaeis spp & Oceanographer & $200-100(1)$ & $16 / 9 / 04$ & \\
\hline & Oceanographer & $350-0(1)$ & $16 / 9 / 04$ & Fig. 7G \\
\hline Chromatonema rubrum & Oceanographer & $777-728(1)$ & $9 / 9 / 02$ & \\
\hline & Oceanographer & $750-625(1), 500-375(1)$ & $15 / 9 / 03$ & \\
\hline $\begin{array}{l}\text { Jeanbouillonia maserati gen. et sp. nov. } \\
\text { LEPTOMEDUSAE (9) }\end{array}$ & & & & see text \\
\hline Modeeria rotunda & & & & see text \\
\hline Laodicea undulata & Oceanographer & $350-0(1)$ & $16 / 9 / 04$ & \\
\hline Clytia hemisphaerica & & & & see text \\
\hline Clytia mccradyi & Atlantis & $100-0$ (2) & 20/9/04 & \\
\hline Zygocanna vagans & Oceanographer & $150-6(2)$ & 26/9/03 & \\
\hline Aequorea sp. & Oceanographer & 200-100 (1), 100-5 (3), 350-0 (1) & $16 / 9 / 04$ & \\
\hline Orchistoma collapsum & & & & see text \\
\hline Dichotomia cannoides & & & & see text \\
\hline Melicertum octocostatum & off Gloucester & $55-0(2)$ & 9/9/04 & \\
\hline
\end{tabular}


366 - F. PAGÈS et al.

TABLE 1 (Cont.). - List of gelatinous species net-collected in the Gulf of Maine over the three cruises including those not commented in the main text.

\begin{tabular}{|c|c|c|c|c|}
\hline Taxa (species number) and species name & Location & Depth in metres (number of specimens) & Date & Remarks \\
\hline \multicolumn{5}{|l|}{ LIMNOMEDUSAE (1) } \\
\hline \multicolumn{5}{|l|}{$\begin{array}{l}\text { Proboscidactyla mutabilis } \\
\text { TRACHYMEDUSAE (7) }\end{array}$} \\
\hline $\begin{array}{l}\text { TRACHYMEDUSAE (7) } \\
\text { Liriope tetraphylla }\end{array}$ & Oceanographer & $350-0(1)$ & $16 / 9 / 04$ & \\
\hline Rhopalonema velatum & Atlantis & $501-464(1)$ & $16 / 9 / 02$ & \\
\hline \multirow{2}{*}{ Halicreas minimum } & Hydrographer & $370-278(1)$ & $17 / 9 / 02$ & \\
\hline & Oceanographer & $750-625(1)$ & $15 / 9 / 03$ & \\
\hline \multirow[t]{3}{*}{ Aglantha digitale } & Oceanographer & $500-375(1)$ & $15 / 9 / 03$ & \\
\hline & Oceanographer & $998-875(1)$ & 23/9/03 & \\
\hline & Wilkinson Basin & $75-0(1)$ & $27 / 9 / 04$ & \\
\hline Crossota rufobrunnea & Oceanographer & $998-875(3), 875-672(6)$ & $23 / 9 / 03$ & Fig. $7 \mathrm{H}$ \\
\hline \multirow{3}{*}{ Pantachogon haeckeli } & Hydrographer & $878-777$ (3), $777-680$ (4), 680-576 (3) & $17 / 9 / 02$ & \\
\hline & Oceanographer & $998-875(2), 875-672(1), 625-500(1)$ & $23 / 9 / 03$ & \\
\hline & Oceanographer & $661-600$ & $16 / 9 / 04$ & \\
\hline \multirow{2}{*}{ Arctapodema ampla } & Oceanographer & $600-0(1)$ & $16 / 9 / 04$ & \\
\hline & Oceanographer & $900-800(3)$ & $3 / 9 / 02$ & \\
\hline \multicolumn{5}{|l|}{ NARCOMEDUSAE (4) } \\
\hline \multirow[t]{5}{*}{ Aeginura grimaldii } & Oceanographer & $686-586(3)$ & $5 / 9 / 02$ & \\
\hline & Hydrographer & 878-777 (1), 777-680 (1), 680-576 (1) & $17 / 9 / 02$ & \\
\hline & Oceanographer & $779-683(8)$ & 8/9/02 & \\
\hline & Oceanographer & $875-672(3), 672-625(3)$ & $23 / 9 / 03$ & \\
\hline & Oceanographer & $1000-625(11)$ & $25 / 9 / 03$ & \\
\hline Cunina fowleri & Oceanographer & $350-0(1)$ & $16 / 9 / 04$ & \\
\hline Cunina peregrina & Oceanographer & surface waters (2) & $15 / 9 / 04$ & \\
\hline \multirow[t]{6}{*}{ Solmissus incisa } & Oceanographer & $683-779(1)$ & $8 / 9 / 02$ & \\
\hline & Oceanographer & $750-625(1), 625-500(2)$ & $15 / 9 / 03$ & \\
\hline & Oceanographer & $684-636(4)$ & $22 / 9 / 02$ & \\
\hline & Oceanographer & $998-875(1)$ & $23 / 9 / 03$ & \\
\hline & Oceanographer & $750-625(1)$ & $25 / 9 / 03$ & \\
\hline & Atlantis & $600-0(1)$ & $21 / 9 / 04$ & \\
\hline \multicolumn{5}{|l|}{ SCYPHOMEDUSAE (8) } \\
\hline \multirow{3}{*}{ Nausithoe atlantica } & Hydrographer & $878-777(2)$ & $17 / 9 / 02$ & \\
\hline & Oceanographer & $625-500(1)$ & $15 / 9 / 03$ & \\
\hline & Oceanographer & $998-875(1)$ & $23 / 9 / 03$ & \\
\hline \multirow[t]{2}{*}{ Nausithoe punctata } & Atlantis & $124-88(2)$ & $16 / 9 / 02$ & Fig. 7 I \\
\hline & Oceanographer & $350-0(3)$ & $16 / 9 / 04$ & \\
\hline Atolla vanhoeffeni & Oceanographer & $875-750(2), 750-625(1)$ & $25 / 9 / 03$ & \\
\hline & Oceanographer & $600-500$ & $16 / 9 / 04$ & \\
\hline & Atlantis Canyon & $600-0(1)$ & $21 / 9 / 04$ & \\
\hline Atolla wyvillei & Oceanographer & $625-500(1)$ & $15 / 9 / 04$ & \\
\hline Periphylla periphylla & Oceanographer & $778-680(1)$ & $5 / 9 / 02$ & \\
\hline & Oceanographer & $850-750(1)$ & $25 / 9 / 04$ & \\
\hline & Oceanographer & $600-0(1)$ & $16 / 9 / 04$ & \\
\hline Phacellophora camstchatica & Lydonia & surface waters (2) & $22 / 9 / 03$ & \\
\hline Pelagia noctiluca & Georges Basin & $210-185(1)$ & $20 / 9 / 03$ & \\
\hline & Atlantis & $100-0(2)$ & 20/9/04 & \\
\hline & Atlantis & $600-0(1)$ & $21 / 9 / 04$ & \\
\hline Poralia sp. & Hydrographer & $878-777(1)$ & $17 / 9 / 02$ & \\
\hline $\begin{array}{l}\text { CTENOPHORA (3) } \\
\text { Tortugas Red Cydippid }\end{array}$ & & & & \\
\hline Tortugas Red Cydippid & Hydrographer & $700-600(1)$ & $17 / 9 / 02$ & \\
\hline (sensu G.R. Harbison) & Oceanographer & 681-631 (1) & $22 / 9 / 02$ & \\
\hline & Oceanographer & $625-500(1)$ & $15 / 9 / 03$ & \\
\hline & Oceanographer & $998-875(1)$ & $23 / 9 / 03$ & \\
\hline Pleurobrachia pileus & & & & see text \\
\hline Beroe sp. & & & & see text \\
\hline MOLLUSCA (6) & & & & \\
\hline Corolla calceola & Oceanographer & $375-2(2)$ & $25 / 9 / 03$ & \\
\hline Carinaria $\mathrm{sp}$ & Oceanographer & $100-5(1)$ & & \\
\hline Pterotrachea coronata & Atlantis & $124-88(1)$ & $16 / 9 / 02$ & \\
\hline Pterotrachea hippopodius & Atlantis & $124-88(1)$ & $16 / 9 / 02$ & \\
\hline Firoloida desmaresti & Oceanographer & surface waters (1) & $15 / 9 / 04$ & \\
\hline Phyllirhoe bucephala & Oceanographer & $100-5(3)$ & $16 / 9 / 04$ & \\
\hline TÚNICATA (3) & & & & \\
\hline Salpa fusiformis & Oceanographer & $350-0$ (many) & $16 / 9 / 04$ & \\
\hline & Atlantis & $600-0$ (many) & $21 / 9 / 04$ & \\
\hline Cyclosalpa affinis & Nantucket Sound & Surface (1 colonial) & 7/9/02 & \\
\hline Thalia democratica & Georges Basin & 35-0 (many), 60-35 (few) & $11 / 9 / 03$ & \\
\hline & Georges Basin & $85-60$ (few), $110-85$ (very few) & $11 / 9 / 03$ & \\
\hline & Georges Basin & $10-0$ (many) & $24 / 9 / 04$ & \\
\hline
\end{tabular}



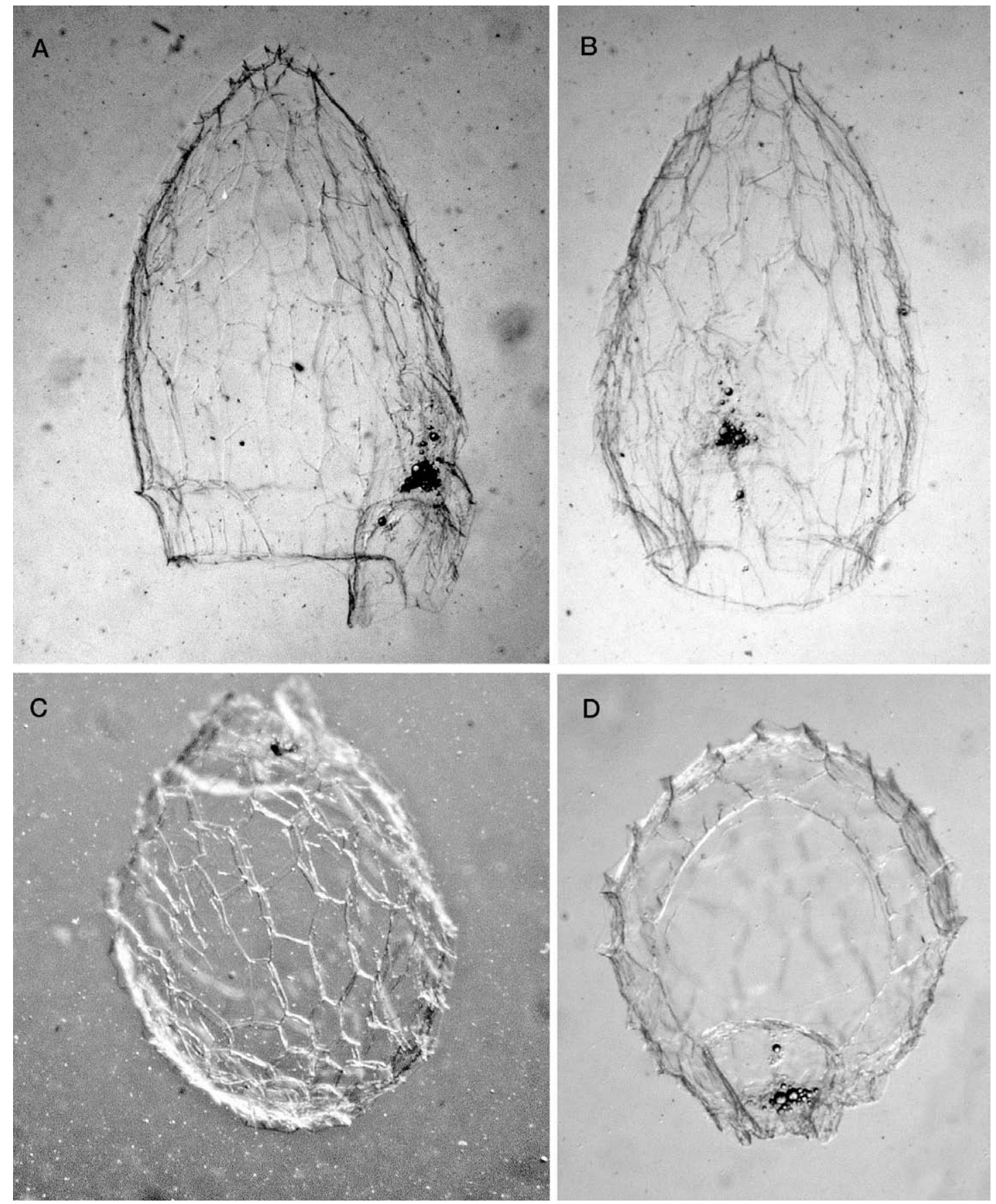

FIG. 2. - Anterior nectophore of Gilia reticulata, $5 \mathrm{~mm}$ high: A, lateral view. B, dorsal view. C, apical view. D, ostial view.

siphonophore and one anthomedusan were identified as new species. Both are described in the following systematic account that includes morphological descriptions of little-known species.

Phylum CNIDARIA Verrill, 1865

Class HydROIDOMEDUSAE Claus, 1877

Subclass SiPHONOPHORAE Eschscholtz, 1829

Order CALYCOPHORA Leuckart, 1854
Family DIPHYIDAE Quoy and Gaimard, 1827

Subfamily GiLiInAE Pugh and Pagès, 1995

Gilia reticulata (Totton, 1954)

(Fig. 2A-D)

Material: One anterior nectophore collected in Oceanographer Canyon $\left(40^{\circ} 11.8^{\prime} \mathrm{N}, 67^{\circ} 57.8^{\prime} \mathrm{W}\right)$ between 686 and $586 \mathrm{~m}$ depth on 5 September 2002. One anterior nectophore and three bracts collected in Oceanographer Canyon $\left(39^{\circ} 52.7^{\prime} \mathrm{N}, 68^{\circ} 48.0^{\prime} \mathrm{W}\right)$ between 777 and $678 \mathrm{~m}$ depth on 9 September 2002. One anterior nectophore collected in Lydonia Canyon $\left(40^{\circ} 19.8^{\prime} \mathrm{N}, 67^{\circ} 40.9^{\prime} \mathrm{W}\right)$ between 678 and $634 \mathrm{~m}$ on 21 September 2002. 


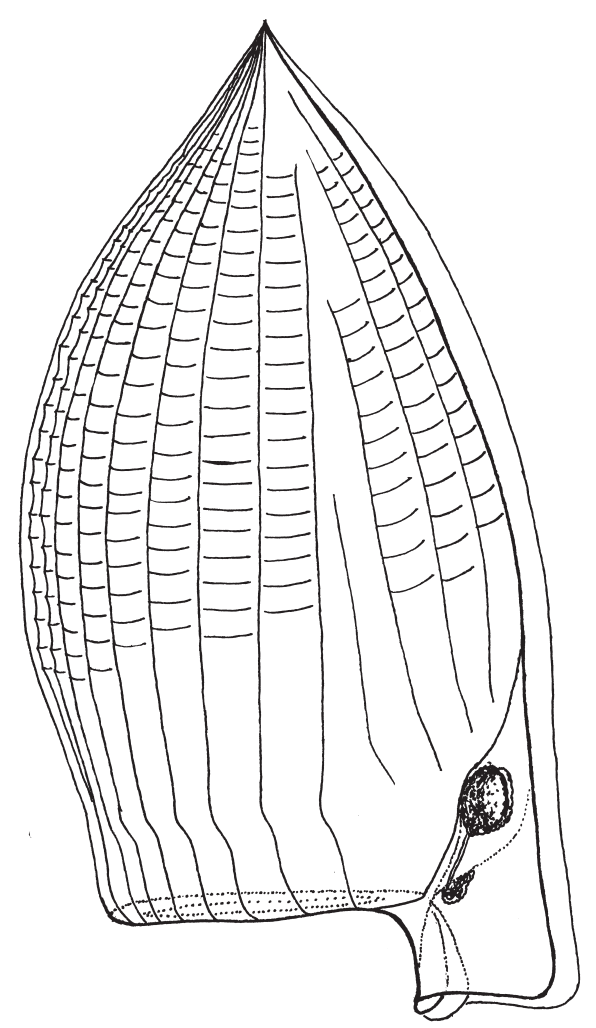

FIG. 3. - Lateral view, slightly ventral, of the anterior nectophore of Lensia quadriculata sp. nov. Nectophore height $6 \mathrm{~mm}$.

Remarks: Pugh and Pagès (1995) established the new genus Gilia when they described the eudoxid stage of this reticulated species and wrote a complete description of the nectophores with detailed drawings. The photographs of the anterior nectophore (Fig. 2) complement the previous study as they show some little-known features of a pristine specimen. The network of ridges forms a pattern of hexagons and pentagons. Below the velar ridge, all ridges are orientated in the vertical plane (Fig. 2AB) and the hydroecium is large and deep (Fig. 2D). The nectophore perimeter (Fig. 2D) does not show concave facets between the ridges, although the ridge walls can cause this impression. The nectophore apex is rounded, not pointed. Cairns et al. (2002) reported on this species only in the Pacific coast of USA and Canada.

\section{Subfamily DiPHYINAE}

\section{Lensia quadriculata sp. nov.}

(Figs. 3, 4A-D, 5A)

Type material: Three anterior nectophores (one holotype and two paratypes) collected by a Mocness haul in Oceanographer Canyon waters $\left(39^{\circ} 52.7^{\prime} \mathrm{N}, 68^{\circ} 48.0^{\prime} \mathrm{W}\right)$ in the 777 to $678 \mathrm{~m}$ depth range on
9 September 2002 ; seawater temperature 4.5 to $4.8^{\circ} \mathrm{C}$, seawater salinity 34.95 to 34.97 psu.

Additional material: One anterior nectophore collected by a Mocness haul in Oceanographer Canyon waters $\left(40^{\circ} 44.3^{\prime} \mathrm{N}\right.$, $68^{\circ} 02.6^{\prime} \mathrm{W}$ ) in the 998 to $875 \mathrm{~m}$ depth range on 23 September 2003. Three anterior nectophores collected at $1049 \mathrm{~m}$ depth in Suruga Bay, Japan ( $\left.34^{\circ} 47.1^{\prime} \mathrm{N}, 138^{\circ} 36.6^{\prime} \mathrm{E}\right)$ on 28 March 1985 in the horizontal haul 85131 during the cruise TO-84-23 conducted by the Tokai University. One anterior nectophore collected at $790 \mathrm{~m}$ depth in Suruga Bay on 13 November 1992 in the horizontal haul 92006 of the cruise TO 92-21. Holotype deposited at the Smithsonian Institution. Paratypes deposited at the Smithsonian Institution, Tokai University and the Institut de Ciències del Mar.

Etimology: quadriculata, small square, Latin, feminine; from quadrus, square and culata, small.

Description: Anterior nectophore small and very fragile, $6 \mathrm{~mm}$ high, $3 \mathrm{~mm}$ in maximum (central) dorso-ventral depth, $2.9 \mathrm{~mm}$ in maximum (central) left-right width. The surface consists of thin vertical and horizontal ridges crossing at right angles and at equal intervals forming a quadrilled pattern. Five sets (1 dorsal, 2 dorso-lateral and 2 ventro-lateral) of 3 longitudinal ridges each extend from the pointed apex down towards the ostium, which is reached only by the central dorsal ridge and the dorso-lateral ridges. More longitudinal ridges ( 2 ventral, 5 left ventro-lateral, 5 right-ventro-lateral, 3 left dorso-lateral and 3 right dorso-lateral) run from below the apex downwards, all reaching the ostium except the 2 ventral ones. A furrow grooves from the apex to the ostium between the ventro-lateral and the dorso-lateral ridges. Twenty ridges join the ostium. About 30 transversal ridges cross the longitudinal ones perpendicularly between the somatocyst level and the apex giving rise to a characteristic quadrilled pattern of ridges. A constriction surrounds the nectophore at the somatocyst level but does not form a velar ridge. The nectosac occupies the subumbrellar cavity almost completely. The somatocyst is short, oval in shape, wider $(1 \mathrm{~mm})$ than it is high, with a short pedicular canal, completely orange in colour (Figs. 3, 4, 5A). The hydroecium is deep, bell-shape, opened ventrally, with the apical surface above the ostium level. The mouth-plate is composed of two basal lamellae slightly overlapped in the centre. The velum is very narrow.

A posterior nectophore partially distorted but attributable to this species was also found in the same sample that contained the holotype. However, we are waiting for new material in good conditions to be captured to make a correct description. The eudoxid is unknown. 

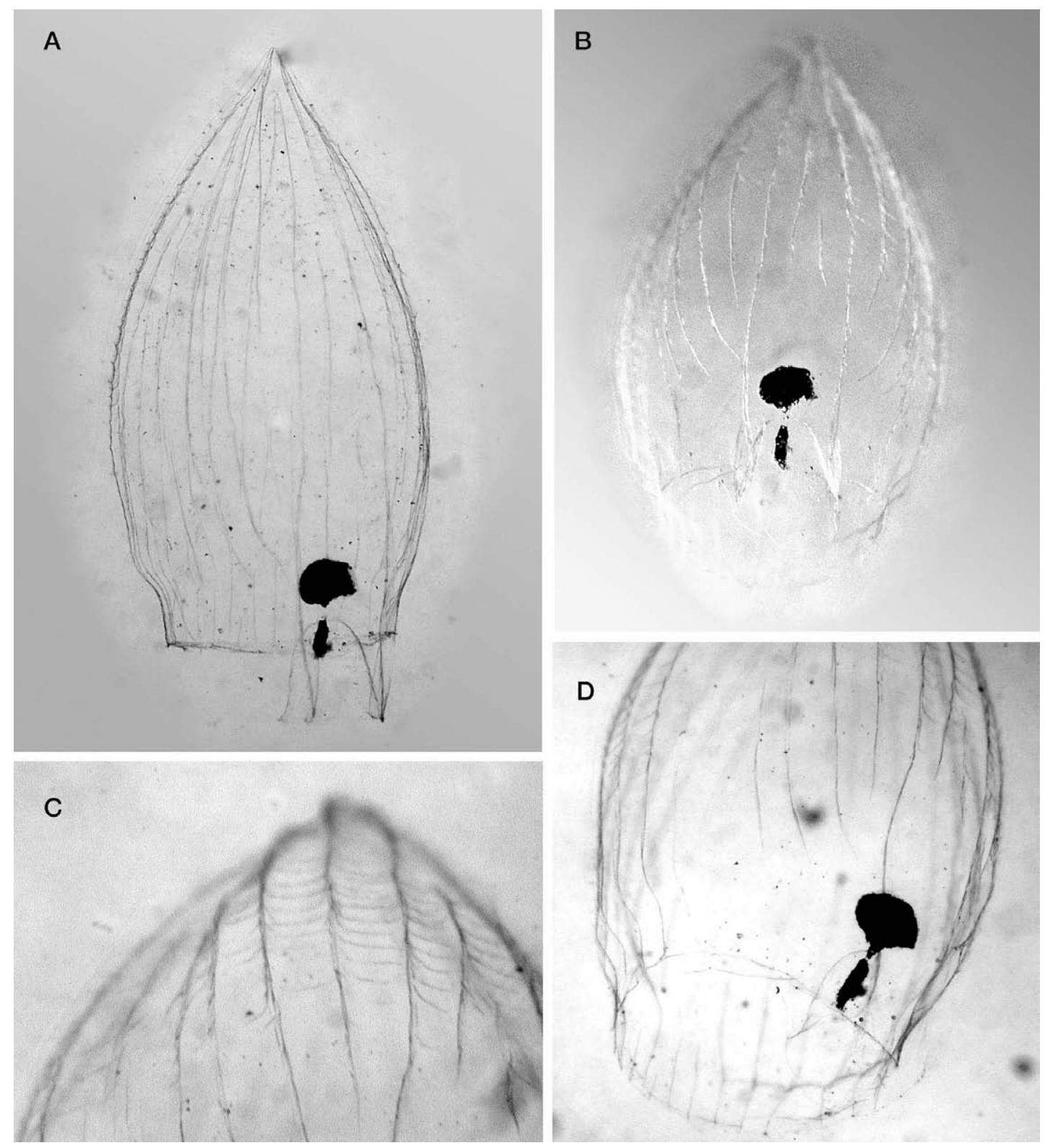

FIG. 4. - Holotype of Lensia quadriculata sp. nov., nectophore $6 \mathrm{~mm}$ high: A, ventro-lateral view. B, ventro-ostial view. C, detail of the quadrilled pattern of crossed ridges near the apex. D, ostio-lateral view.

Remarks: Some years before these nectophores were collected in the Gulf of Maine, the University of Tokai in Shimizu (Japan) loaned FP a large collection of siphonophores sampled in the Bay of Suruga over the period 1981 to 1992. Several new species were identified in the collection and one of them was the Lensia species described here. These specimens were laterally flattened and it was decided to postpone the description until pristine ones were captured.

The quadrilled pattern of crossed ridges suggests that the new species could be phylogenetically clos- er to Gilia reticulata (Fig. 2, see also Pugh and Pagès, 1995). However, the multistriate diphyinae Lensia ajax Totton, 1941, and L. lelouveteau Totton, 1941 are also quite close since both show the pattern of five groups of longitudinal ridges. The marked honeycomb arrangement of the ridges in G. reticulata is easily distinguishable from the cobweb pattern (radiating strand more prominent than the cross connecting ones) of L. quadriculata. The distinction is more difficult when comparing the nectophore of L. quadriculata with preserved samples of L. ajax and L. lelouveteau. Nevertheless, L. ajax somatocyst 

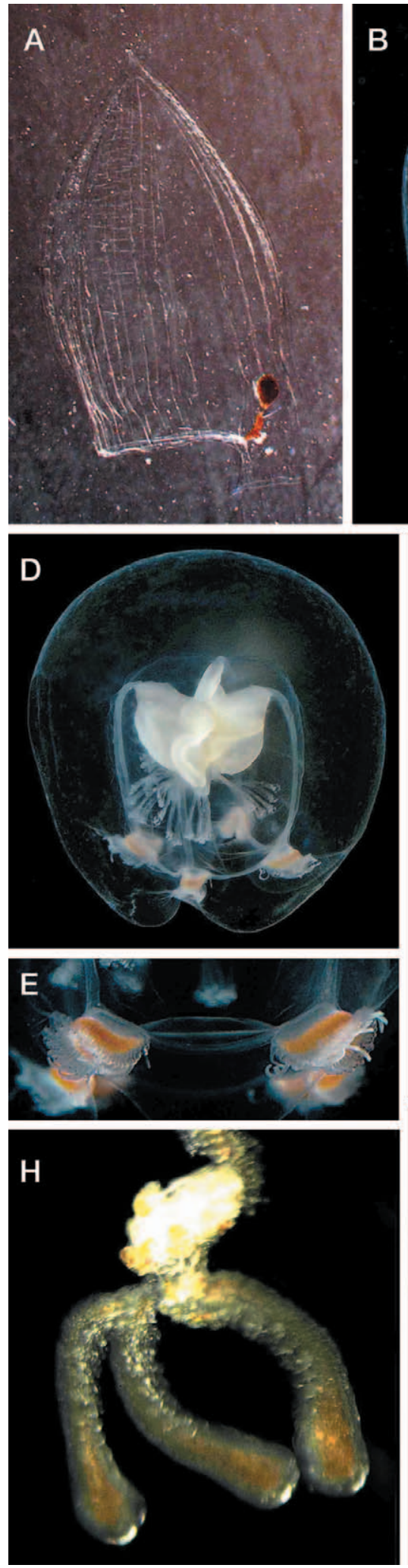

B
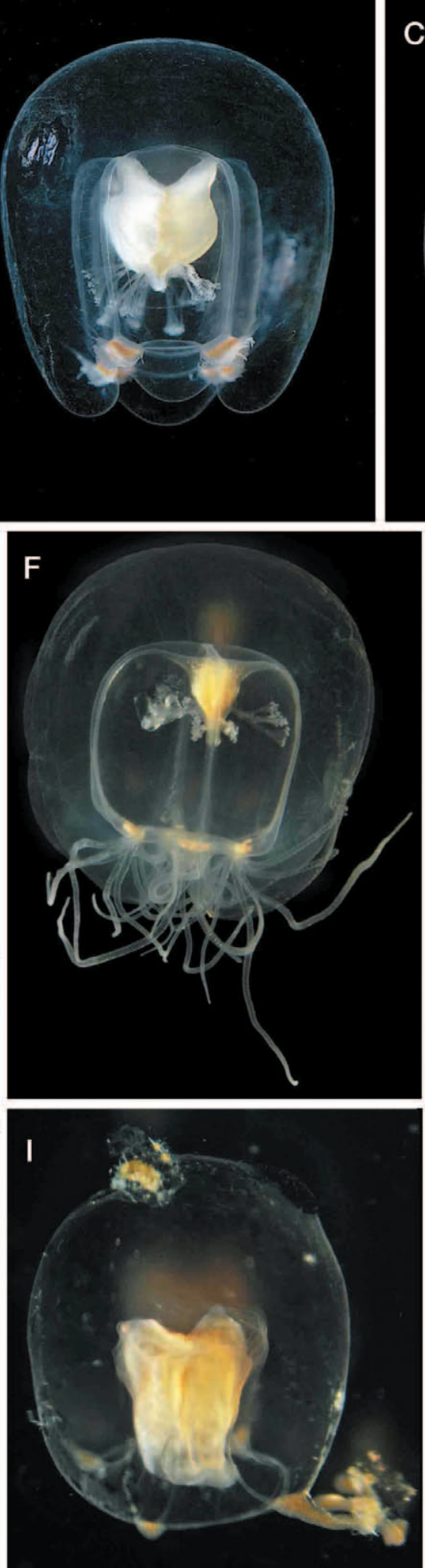

C
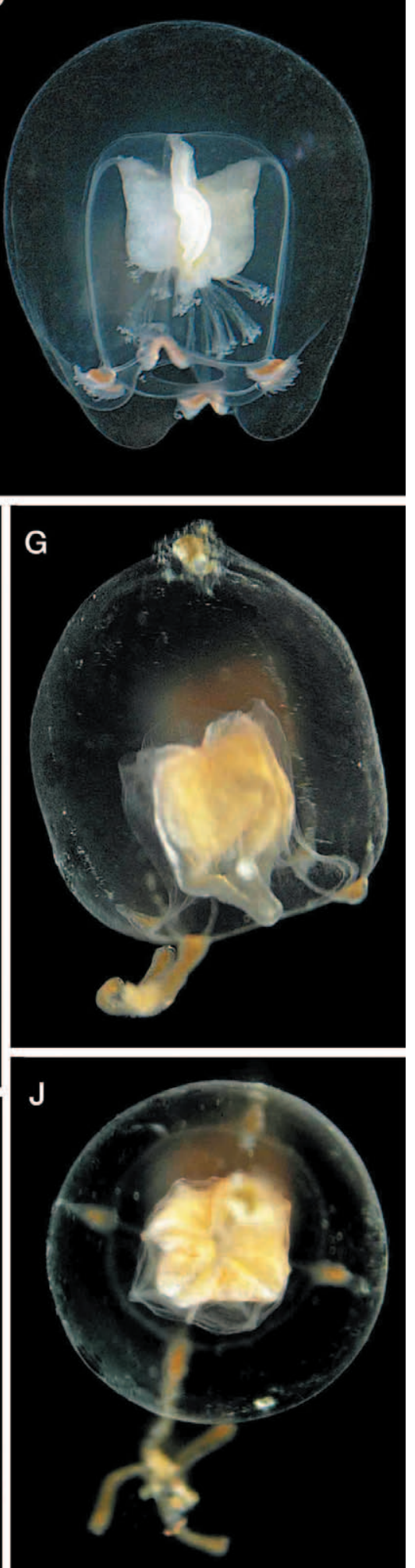

FIG. 5. - A: Lensia quadriculata sp. nov., holotype in lateral view, nectophore $6 \mathrm{~mm}$ high. Bougainvillia principis, umbrella height $12 \mathrm{~mm}$ : B, interradial view. C, perradial view. D, apico-lateral view. E, detail of the umbrella margin showing the "epaulettes" and the marginal bulbs and tentacles. Bougainvillia platygaster, umbrella $5 \mathrm{~mm}$ high: F, perradial view. Jeanbouillonia maserati, gen. nov. et sp. nov., umbrella 3 $\mathrm{mm}$ high: $\mathrm{G}$ and I, lateral view; note a radiolarian on the apical exumbrellar surface. $\mathrm{H}$, trident-shape distal end of the principal tentacle; the whitish spot is a radiolarian. J, apical view. (Figs. 6B-J: (C) Bathybiologica A/S). 
is oblique and higher than it is wide, and although $L$. lelouveteau somatocyst is very similar to L. quadric$u l a t a$, the former species shows a marked velar ridge and the ventro-basal margins of the hydroecium are well rounded (Totton, 1965). Examination of three anterior nectophores of L. lelouveteau collected in Suruga Bay (Pagès, unpublished data) confirmed the lack of horizontal ridges in this species. We prefer to assign the new species to the genus Lensia based on the presence of the five sets of vertical ridges. The discovery of the eudoxid would keep it in the genus Lensia or move it to Gilia.

\section{Sub-Class ANTHOMEduSAe Haeckel, 1879 Order FILIFERA Kühn, 1913 \\ Family BougainVILliIDAE, Lütken, 1850}

Bougainvilllia principis (Steenstrup, 1850) (Fig. 5B-E)

Material: One large specimen collected in Georges Basin $\left(42^{\circ} 25.3^{\prime} \mathrm{N}, 67^{\circ} 31.3^{\prime} \mathrm{W}\right)$ between $290 \mathrm{~m}$ depth and the sea surface on 25 September 2004. Bottom depth $297 \mathrm{~m}$. Seawater temperature on surface, $50 \mathrm{~m}$ and $270 \mathrm{~m}$ depth was $15.4,4.7$ and $8.2^{\circ} \mathrm{C}$ respectively. Salinity at these depths was $32.0,32.8$ and 34.9 psu respectively.

Description: Umbrella globular, $12 \mathrm{~mm}$ high and $11 \mathrm{~mm}$ wide, with homogenously thick mesoglea that extends as "epaulettes" in the interradial segment below the subumbrella opening (Fig. 5B-E). No peduncle. Manubrium cruciform, yellowish, with long arms, high adradial stomach walls, narrow perradial sides and deep interradial furrows that occupy half of the subumbrella height. Radial canals 4, linear, wide. Ring canal as wide as radial ones. Gonads flat, whitish, covering the adradial stomach walls almost completely. Basal trunk of oral tentacles very short, branched six times, with a terminal cnidocyst cluster that reaches the subumbrellar opening when relaxed. Marginal bulbs $\wedge$-shaped, red-brown in colour, with about 40 short tentacles per bulb arranged in a single row although this can look like two rows due to bulb contraction; each tentacle with a rounded, black adaxial ocelli at its base. Velum moderately broad.

Remarks: The specimen is a large adult according to the umbrella size, shape and size of the manubrium, gonads, and number of tentacles. The description fits quite well with the diagnosis for Bougainvillia principis given by Kramp (1959), by Vanucci and Rees (1961, Table VI) in their review of the genus Bougainvillia, and by Edwards (1966, Table 4).
However, no figures in the literature illustrate a specimen similar to that reproduced in this study.

The $\wedge$-shape of the marginal bulbs could misidentify the species since another three species, Bougainvillia macloviana Lesson, 1843, B. multitentaculata Foerster, 1923 and B. superciliaris (L. Agassiz, 1849) (see Table VI in Vanucci and Rees, 1961) are known to have it. But these three species have peduncle. However, we believe that tentacular bulbs become $\Lambda$-shaped in large specimens due to umbrella contraction. The re-examination of young specimens of $B$. macloviana from the Magellan channels (Pagès and Orejas, 1999) revealed that all of them displayed linear shaped bulbs. Likewise Figures 5 B-D show that the lower half of the umbrella is not as wide as the upper one, which suggests that the living specimen contracted when the photographs were taken.

Our specimen shows a short mesogleal space above the stomach that could be interpreted as a peduncle. But this space is not the case since the radial canals are connected with the stomach base without turning down and therefore without giving rise to a peduncle. After preservation, this mesogeal space became even more reduced. The adradial walls of the stomach are rectangular shaped.

From the hydroid, Edwards (1966) reared medusae up to $6.19 \mathrm{~mm}$ in diameter and $5.3 \mathrm{~mm}$ in height, which was the first stage that he considered fully adult. Both the number of tentacles per bulb and the branching of oral tentacles in this specimen were 19 and 8 respectively. The largest medusae collected in the Firth of Clyde waters measured up to $6.55 \mathrm{~mm}$ in diameter, had 23 tentacles per bulb and oral tentacles branched 6 to 7 times.

To our knowledge the geographical position of the specimen captured represents the most southern and western record in the north Atlantic (Kramp, 1959; Shih et al., 1971; Cairns et al., 2002). Kramp (1959) placed this species in a group of nine with predominant northern-boreal or arctic-boreal distribution. A possible explanation for this occurrence is the transport of the specimen from Greenland waters and its advection into Georges Basin through the Northeast Channel, which is supported by its large size and mature stage. Kramp (1942) found several specimens ( 2 to $11 \mathrm{~mm}$ wide) on the south-western coast of Greenland. The hydrography of Georges Bank and the adjacent Gulf of Maine is very complex and there are nine water masses within an area of about $300 \mathrm{~km}$ in diameter (Flagg, 1987). 
Bougainvilllia platygaster (Haeckel, 1879) (Fig. 5F)

Material: One specimen collected in Oceanographer Canyon waters $\left(40^{\circ} 09.0^{\prime} \mathrm{N} 68^{\circ} 09.8^{\prime} \mathrm{W}\right)$ in the 200 to $100 \mathrm{~m}$ depth range on 16 September 2004.

Description: Umbrella globular, slightly cubic, 5 $\mathrm{mm}$ high and $5 \mathrm{~mm}$ wide, with homogenous thick mesoglea that extends as "epaulettes" in the interand adradial segments below the subumbrellar opening. No peduncle. Manubrium short, one-third of subumbrellar height, with wide square base. Radial canals 4, wide, linear. Ring canal narrow. Gonads interradial, flat, yellowish. Basal trunk of oral tentacles short, branched four times, with a terminal cnidocyst cluster. Marginal bulbs slightly crescent, red-brown in colour, with about 10 long tentacles per bulb, arranged in one row; each tentacle with a rounded, black adaxial ocelli at its base. Velum moderately broad.

Remarks: Medusa buds were not observed on the radial canals of the specimen but this absence was not considered of taxonomic value by Bouillon (1995, p. 227). He also noticed the lack of good illustrations of the specific characters of this species in the literature. In life, the manubrium is short (Fig. $5 \mathrm{~F})$, not as short as shown in drawings of preserved specimens in which it looks flat (e.g. Pagès et al., 1992, Fig. 2; Schuchert 1996, Fig. 16) but as it was illustrated by Bouillon (1995, Fig. 1A). Cairns et al. (2002) did not report this species in US and Canadian waters.

Family JEAnbouILLONIIDAE fam. nov.

Diagnosis: as for the genus Jeanbouillonia.

Jeanbouillonia maserati gen. nov. et sp. nov. (Figs. 5G-J, 6)

Material: One specimen collected in Georges Basin $\left(42^{\circ} 25.3^{\prime} \mathrm{N}\right.$ $67^{\circ} 31.3^{\prime} \mathrm{W}$ ) between $290 \mathrm{~m}$ depth and the sea surface on 25 September 2004. Bottom depth 297 m. Holotype deposited in the Smithsonian Institution

Etimology: This genus was named after Prof. Jean Bouillon, in recognition of his remarkable work in the biology and systematics of hydrozoans and for his friendship and support through many years. The specific name maserati (name in apposition) is given for the trident-shaped main tentacle, figuratively a nexus between the three families.

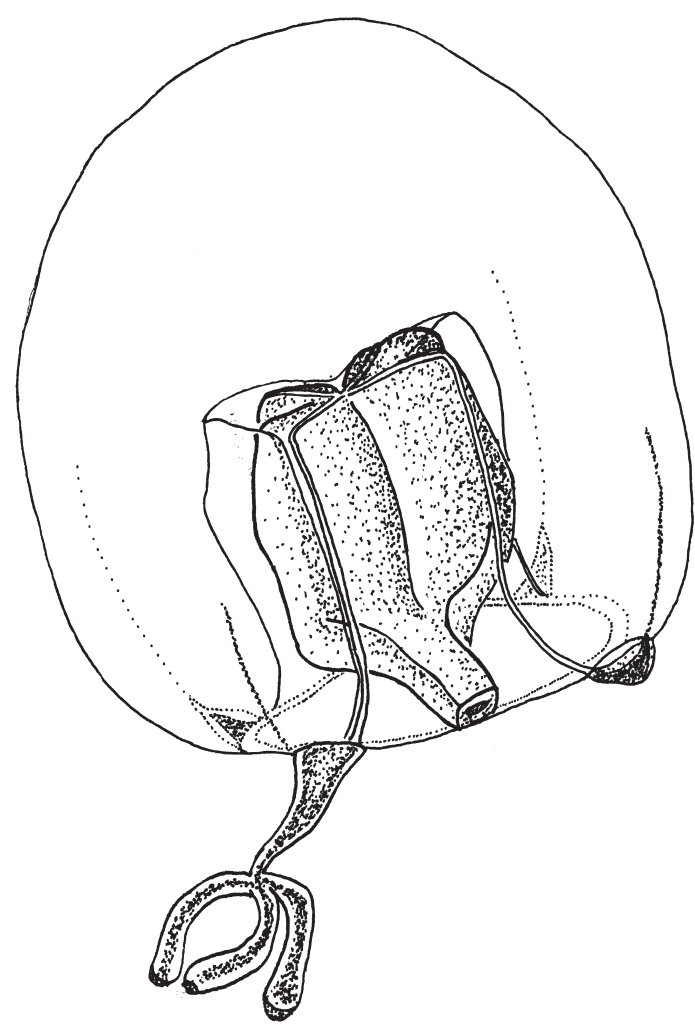

FIG. 6. - Lateral view of the holotype of Jeanbouillonia maserati, gen. nov. et sp. nov., umbrella $3 \mathrm{~mm}$ high.

Description: Umbrella globular, symmetrical, without apical projection, $3 \mathrm{~mm}$ in diameter. The subumbrellar cavity occupies the lower half of the umbrella. About $1.5 \mathrm{~mm}$ of mesoglea above the subumbrella. Manubrium cruciform, orange, $1 \mathrm{~mm}$ high, with perradial ridges and deep interradial furrows, filling almost all the subumbrellar cavity. Mouth with four intangible lips that reach the subumbrellar opening. Radial canals 4, as narrow as the ring canal. Gonads flat, yellowish, interradial, extended over the whole manubrium except the perradial ridges. Gonads look like a tongue, wide in the adradius and connected in the lower interradial half of the manubrium, with a vertical furrow in the upper half. Marginal bulbs 4, orange in colour, triangular, isosceles, with 7 to 8 cnidocysts on the top corner, one with a tentacle and three without. One cnidocysts line departs from each marginal bulb upwards to mid-exumbrella. Tentacle $1.5 \mathrm{~mm}$ long, trident-shaped due to three prominent orange terminal branches, with cnidocyst clubs arranged longitudinally on one side. The opposite marginal bulb has no evident tentacle but a rounded knob with cnidocysts at its base; the two other marginal bulbs are rudimentary, atentaculated. 
Diagnosis of the genus Jeanbouillonia: Umbrella globular. Exumbrellar cnidocyst track departing upwards from each marginal bulb. Subumbrellar cavity in the lower half of the umbrella. Manubrium cruciform. Mouth with four simple lips. Radial canals 4, linear. Gonads interradial, extended over the whole manubrium except the perradial ridges. Marginal bulbs 4. Only one tentacle, trident-shaped; opposite marginal bulb with a knob; two remnant bulbs rudimentary, atentaculated.

Remarks: Radiolarians were attached both to the exumbrellar summit and at the base of the forked distal end of the marginal tentacle but they were not removed in order to avoid damaging the only specimen. However, the photographs of the living specimen (Fig. 5G-J) taken shortly after its capture disregard any interpretation of damage. The Euphysora-type morphological appearance (umbrella shaped plus arrangement, shape and number of marginal tentacles; see Bouillon (1978) for a species key) of this anthomedusan contrasts strongly with the cruciform manubrium, the interradial gonads and the simple lips. These three characters neither match with the diagnosis of corymorphids nor with that for tubularids to which the exumbrellar cnidocyst patch could relate. This exumbrellar cnidocyst track is also characteristic of zancleids (see Russell, 1953; Boero et al., 2000; Bouillon et al., 2004) and a few pandeids. Zancleids also share more characters with the new species, namely the interradial gonads and the lateral position of cnidocysts in the tentacle, which nonetheless are not developed in Jeanbouillonia as cnidophores are in zancleids. The four simple lips of Jeanbouillonia are rare but they have also been described in the zancleid Halocoryne frasca Boero, Bouillon and Gravili, 2000, whose tentacular bulbs are also triangular and shelter cnidocysts.

In summary, the morphological features described above are partially shared by at least three families (corymorphids, tubularids and zancleids) but combined together do not fit any known anthomedusan family, which suggests that a new family needs to be established to accommodate this new genus and species in the hydrozoan systematics. We believe that the effort of fitting Jeanbouillonia maserati into any of the above mentioned families, more than being an unconvincing adjustment would cause confusion in hydrozoan systematics.

\author{
Subclass LePTOMEdUSAE Haeckel, 1866 \\ Order CONICA Broch, 1910 \\ Family CAMPANULARIIDAE Johnston, 1837 \\ Clytia hemisphaerica (Linnaeus, 1767)
}

Material: One specimen collected by dipnet in Georges Basin $\left(42^{\circ} 15.8^{\prime} \mathrm{N}, 67^{\circ} 29.1^{\prime} \mathrm{W}\right)$ on 13 September 2003 . Many specimens collected in surface waters off Gloucester Harbour $\left(42^{\circ} 32.1^{\prime} \mathrm{N}\right.$ $70^{\circ} 37.4^{\prime} \mathrm{W}$ ) between 9 and 14 September 2004. Many more specimens collected at the top $10 \mathrm{~m}$ depth of Georges Basin waters $\left(42^{\circ} 26^{\prime} \mathrm{N}, 67^{\circ} 31.0^{\prime} \mathrm{W}\right)$ on 24 to 26 September 2004.

Description: Umbrella hemisphaerical, up to 15 $\mathrm{mm}$ in diameter. Gonads along the distal half of the four radial canals. Tentacles 32, statocysts 2-3 with one statolith between adjacent tentacles.

Remarks: Kramp (1959, p. 147) separated Clytia (Phialidium) languida and C. hemisphaerica in the identification key of the Phialidium species based only on geographic distribution and stated "This medusa (Clytia languida) may hardly be distinguished from $P$. hemisphaericum, ... their hydroids, however, seem to be different". Calder (1991, p. 5860) reviewed the Clytia species inhabiting northwestern Atlantic waters and indicated that both species were probably the same. We concur with this conclusion after examining our specimens. Cairns $e t$ al. (2002) did not report $C$. languida but rather $C$. hemisphaerica on the Atlantic and Pacific coasts of USA and Canada.

Family OrChISTOMIDAE Bouillon, 1984

Orchistoma collapsum (Mayer, 1900)

(Fig. 7A-C)

Material: One specimen collected in Oceanographic Canyon on 16 September 2004 in the 100 to $5 \mathrm{~m}$ depth range. Temperature 13.0 to $283^{\circ} \mathrm{C}$, salinity 34.9 to 36.5 psu.

Description: Umbrella wider (12 $\mathrm{mm})$ than it is high $(9 \mathrm{~mm})$, with a large, gelatinous gastric peduncle. The stomach has a broad $\mathrm{H}$-shape base, with low walls that meander along the peduncle forming four substomachs separated by large $\cap$-shape spaces (Fig. 7A). These substomachs branch dichotomiously giving rise to 8 substomachs with higher stomach walls and crenulated lips, also separated by $\cap$-shape spaces. The radial canals are linear, wide, greenish and slightly jagged on the distal end. They depart from the base of the 8 substomachs, arranged in groups of 5,3,5,3,5,3,5 and 4 that sum 33 radial canals in total. The short gonads are located in the proximal part of the radial canals, very close to the 

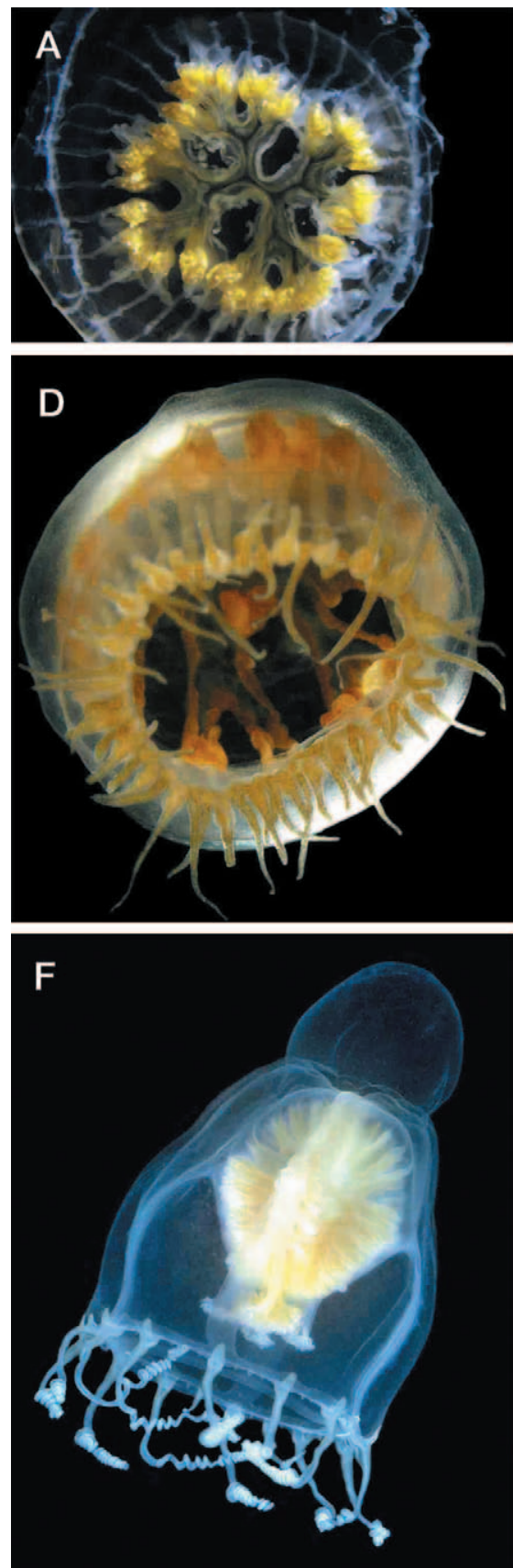
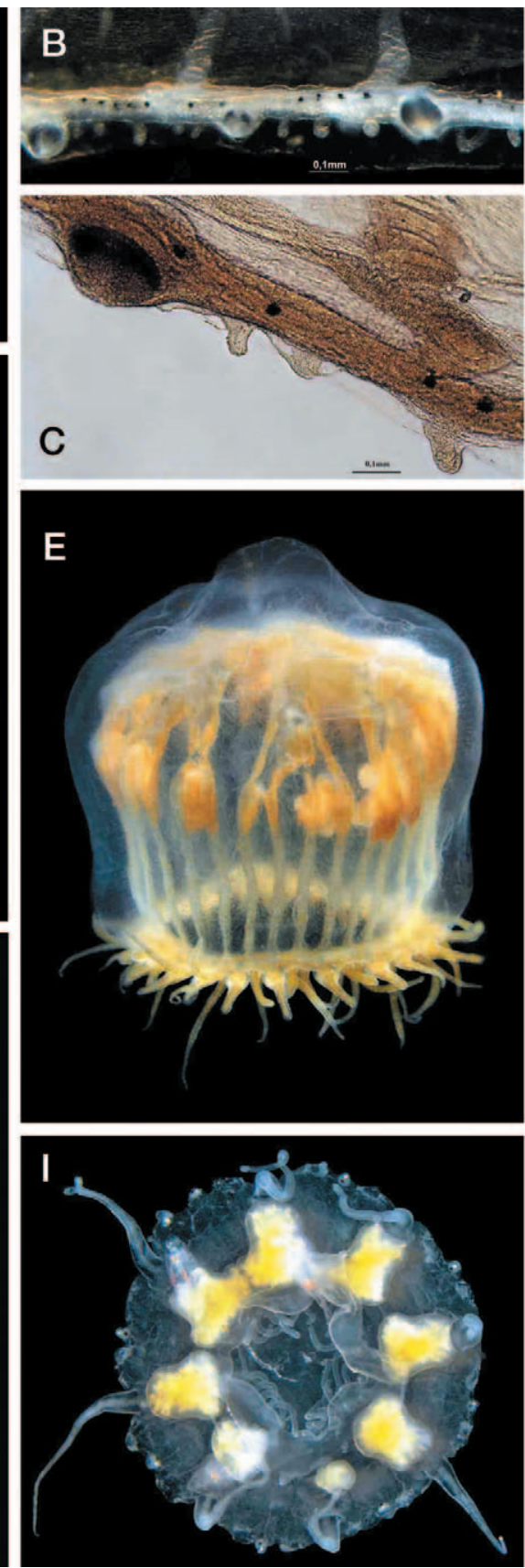
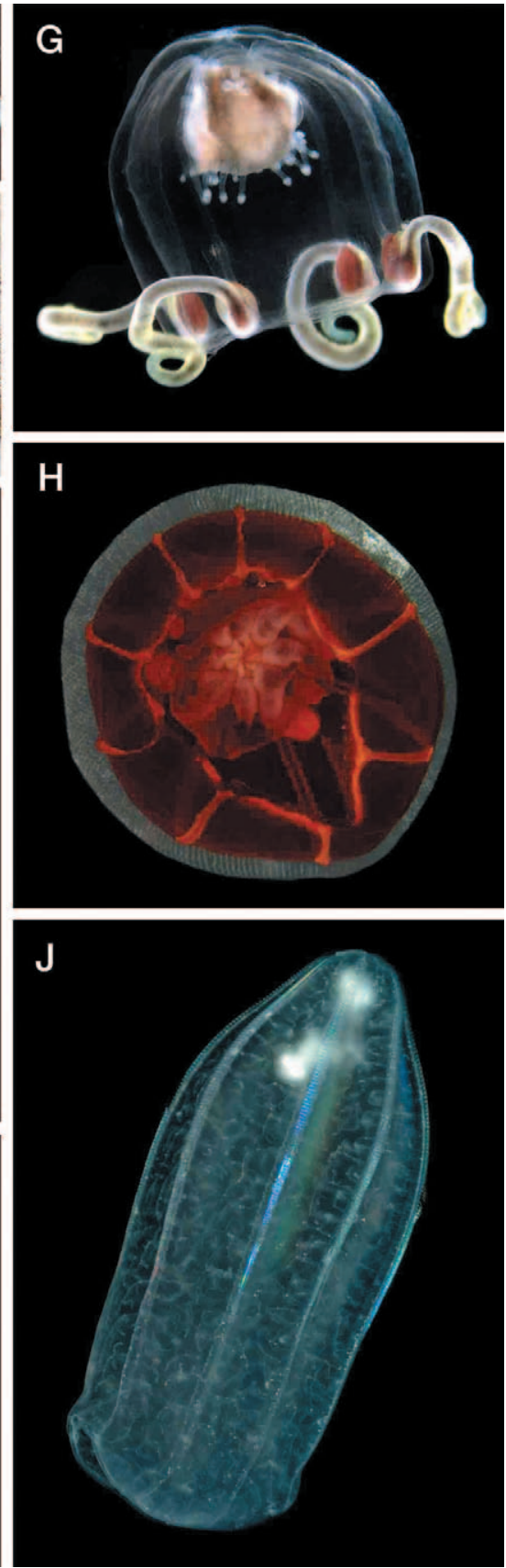

FIG. 7. - Orchistoma collapsum: A, subumbrellar view, umbrella diameter $12 \mathrm{~mm}$. B and C, abaxial view of the umbrella margin showing tentacle bulbs, secondary tentacles and adaxial ocelli. Dichotomia cannoides: D, subumbrellar view, umbrella diameter $3.5 \mathrm{~mm}$. E, apico-lateral view, umbrella $5 \mathrm{~mm}$ high. Leuckartiara octona: F, lateral view, umbrella $15 \mathrm{~mm}$ high. Cytaeis spp.: G, lateral view of umbrella $3 \mathrm{~mm}$ high. Crossota rufobrunnea: H, subumbrellar view, $11 \mathrm{~mm}$ in diameter. Nausithoe punctata: I, subumbrellar view, $10 \mathrm{~mm}$ in diameter; note the specific circular ocelli in the rhopalia. Beroe sp.: J, oral-aboral length $22 \mathrm{~mm}$, with a whitish prey in the pharynx. (Fig. 7A-J: (C) Bathybiologica A/S).

basal, external perimeter of the stomach. The eggs measure $0.2 \mathrm{~mm}$ in diameter and are arranged in two rows along the gonads. The marginal rim has 33 vesicles, each with endodermal dark spots. The primary marginal tentacles are cut at their base; the secondary ones, 4 to 12 between adjacent vesicles, are short, $0.3 \mathrm{~mm}$ in length. Ocelli adaxial, dark, rounded, located in the ring canal without corresponding to the tentacles (Fig. 7 B-C).

Remarks: Bouillon (1984a, p.15) created the family Orchistomidae and included a diagnosis in an attempt to make a new classification for ThecataeLeptomedusae. The new family was, however, justi- 
fied in the following paper (Bouillon, 1984b, p. 88), in regrouping several medusae species formerly placed in the Dipleurosomatidae as Dipleurosoma collapsum (Mayer 1900), or in the Laodiceidae as Orchistoma agariciforme Keller, 1884 and $O$. pileus (Lesson, 1843) among others. Bouillon (1984b) agreed with Kramp (1959, p.132) that some Dipleurosoma species probably did not belong to this genus because the rudimentary tentacles were not laodiceid cordyli. However, illustrations of the anatomy of the tentacles were not provided. The overall good shape of our specimen allowed a microscopical observation of the umbrella margin, which confirmed that the tentacles were rudimentary, without any resemblance to laodiceid cordyli (Fig. 7B-C).

\section{Family Dipleurosomidae Russell, 1953 \\ Dichotomia cannoides Brooks, 1903} (Fig. 7D-E)

Material: One specimen collected in Oceanographic Canyon $\left(40^{\circ} 09.0^{\prime} \mathrm{N}, 68^{\circ} 09.8^{\prime} \mathrm{W}\right)$ between 100 and $5 \mathrm{~m}$ depth on 16 September 2004. Temperature 13.0 to $28.3^{\circ} \mathrm{C}$, salinity 34.9 to $36.5 \mathrm{psu}$.

Additional material examined: More than 50 specimens collected in Papua New Guinea waters by Prof. Jean Bouillon and deposited in the biological collections of the Institut Royal des Sciences Naturelles de Belgique.

Description: Umbrella bell-shape, $5 \mathrm{~mm}$ high, $3.5 \mathrm{~mm}$ wide. Rounded apical projection with mesoglea moderately thick. Radial canals 29 , almost as wide as interradial spaces, orange-brown in colour, derived from a central $\mathrm{H}$-shape canal system in the subumbrella top, whose 4 arms bifurcate three times, although not always regularly. Gonads folded and mainly located along the three bifurcations and the proximal part of the definitive radial canals. Tentacles solid, about 60 , all of similar structure and length, densely crowded, without keeping a numeric correspondence with the radial canals. Manubrium not found.

Remarks: The upward orientation of the tentacles (Brooks, 1903; Kramp, 1959) could be a preservation artifact as it was not observed in the living specimen (Fig. 7 D-E) or in the specimens deposited in Brussels. As Kramp (1959) wrote, and contrary to Brooks's description, we observed only one type of solid tentacle, which was variable in length due to contraction as the shorter tentacles have more rounded distal ends. However, the specimens deposited in Brussels have tentacles of two sizes like those originally illustrated.
As there was no proper manubrium in our specimen and the one figured by Brooks was odd, large and simple (1903, plate 1 Fig. 1), which was also copied and poorly described by Kramp (1959) in spite of having found 14 specimens 3 to $8 \mathrm{~mm}$ in diameter, we decided to examine several specimens collected by Prof. Jean Bouillon in waters of Papua New Guinea. These specimens range between 2 and $5 \mathrm{~mm}$ in height and none of them has a tubular manubrium with simple mouth. However, all of them have a polygonal manubrium that occupies almost half the subumbrella in the largest individuals, with the same number of lips and branches before the last bifurcation. This relation led us to believe that the manubrium of our specimen could have about 14 lips. This species shows a wide geographical distribution with few records: Bahamas Islands (Brooks, 1903), Virgin Islands and Delaware Bay (Kramp, 1959), South China Sea (Xu and Zhang, 1978) and Papua New Guinea (Bouillon, 1984).

Family TIARANNIDAE Russell, 1940

Modeeria rotunda (Quoy and Gaimard, 1827) (Fig. 8A-C)

Material: One specimen collected in Oceanographer Canyon $\left(40^{\circ} 09.5^{\prime} \mathrm{N}, 67^{\circ} 57.4^{\prime} \mathrm{W}\right)$ between 494 and $378 \mathrm{~m}$ depth on 7 September 2002 . Seawater temperature 5.7 to $6.4^{\circ} \mathrm{C}$, salinity 34.98 to $35.02 \mathrm{psu}$.

Description: Umbrella globular, $24 \mathrm{~mm}$ high and $26 \mathrm{~mm}$ wide in the base. Mesoglea very thick, $6 \mathrm{~mm}$ from stomach base to umbrella summit. Subumbrellar cavity pyriform (Fig. 8A). Manubrium red, cruciform, looking like a pyramid of 8 sides in apical view, the wider sides perradial, the narrower interradial, reaching mid-subumbrella. The manubrium extends as four perradial pouches attached to the subumbrella (Fig. 8B) (Bouillon, 1985 , p. 144). Radial canals 4, thin, that depart from the lower third of the manubrium, below the lower end of the gonads (Fig. 8B), and bend inwards following four, ovoid, mesogleal convexities that can look bilobate (Fig. 8C). The radial canals run downwards to the ring canal but one of them bifurcates beneath the mesogleal convexity (Fig. 8A) and five join the ring canal. Mouth large with four lips slightly crenulated. Subumbrellar opening slightly square. Tentacles 32, whitish, with slight lateral crenulations. Tentacular bulbs with red, rounded endoderm. Gonads adradial, forming horizontal folds on the manubrium and perradial gastric pouches, connected apically in the interradii and filling all the 

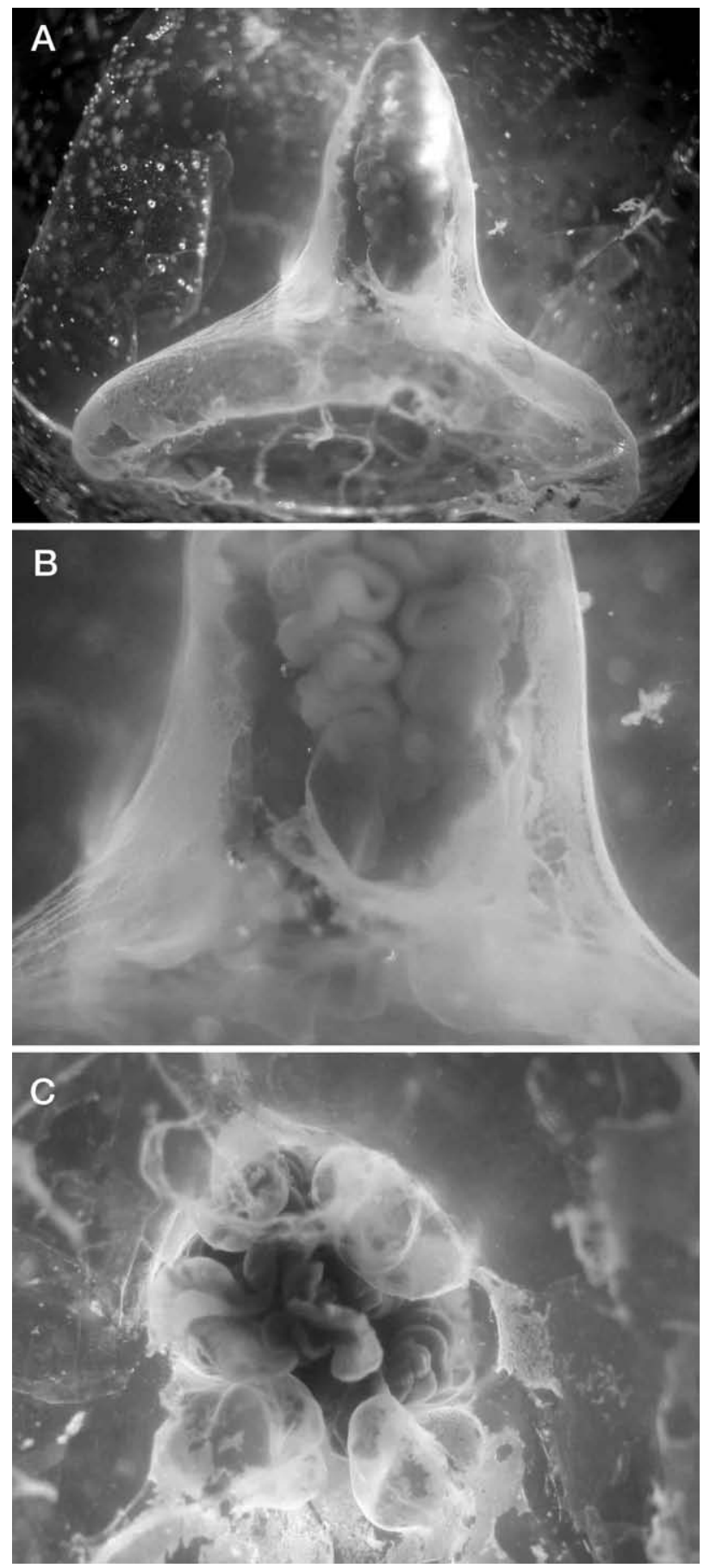

FIG. 8. - Modeeria rotunda, $24 \mathrm{~mm}$ umbrella height: A, lateral view. Note the pyriform subumbrella with the oval-shape perradial convexity. B, detail of the gonads and the perradial convexity. C, subumbrellar view of the manubrium surrounded by the four perradial convexities.

manubrial subumbrella. Cordyli-like structures 1 to 3 , usually 2 , between marginal tentacles.

Remarks: Modeeria (Tiaranna) rotunda descriptions show remarkable differences in the growth stage and size when comparing the text and figures from several sources in the literature (Ranson, 1936; Kramp, 1959; Edwards, 1963, 1973). For instance, the pyriform subumbrella and the four conspicuous mesogleal convexities characteristic of large specimens are rarely mentioned. To our knowledge, Hartlaub (1917, Fig. 341 as Rotundula brochii) provided the first and only drawing of the pyriform subumbrella from a specimen 25 to $30 \mathrm{~mm}$ in diameter. A morphology which was also shown in the photograph of a large specimen published by Wrobel and Mills (1998, p. 34). The mesogleal convexities were described by Ranson (1936, p. 68, Pl. 1, Figs. 10-11) as mesogleal spurs (éperons). It is interesting to note that the specimen figured (Ranson 1936, Pl. 1, Fig. 11) had 5 radial canals and 5 mesogleal convexities. The mesogleal convexities were photographed by Brinckmann-Voss and Arai (1998, Fig. 12C) in a specimen $20 \mathrm{~mm}$ wide and $17 \mathrm{~mm}$ high. They argued that the inwards bending of the radial canals and the connection to the manubrium formed a subumbrellar pocket. However, Edwards had used the last term previously (1973, Fig. 2 A, C-D) for designating the interradial spaces above the pyramidal manubrium in a specimen $8.46 \mathrm{~mm}$ in diameter and $6.37 \mathrm{~mm}$ high. The use of the term "subumbrellar pocket" could cause some confusion in interpreting explanations from both papers. For example, neither of these spaces exists in our specimen due to the large size of the gonads. Brinckmann-Voss (pers. comm. on 11 March 2005) believes that "subumbrellar pocket" was a poor expression and that Edwards could not refer to the same space because of the young age of his specimens.

The position of the gonads varies depending on each author. Edwards (1973, p. 577) wrote " Gonads have begun to form as sinuous folds in the walls of the stomach immediately adjacent to its perradial attachments to the subumbrella...". Bouillon partially concurred (1985, p. 145) in considering that they are located over the interradial surface of the manubrium as well as over the perradial lobes. Ranson (1936) and Brinckmann-Voss and Arai (1998) placed them as adradial. We believe that the three explanations are correct but adradial is the most exact location because perradial is the attachment of the stomach pouches and the interradii are free of gonads except in the apical part of the manubrium (Fig. 8). Cairns et al. (2002) reported this species only on the Pacific coast of USA and Canada. 

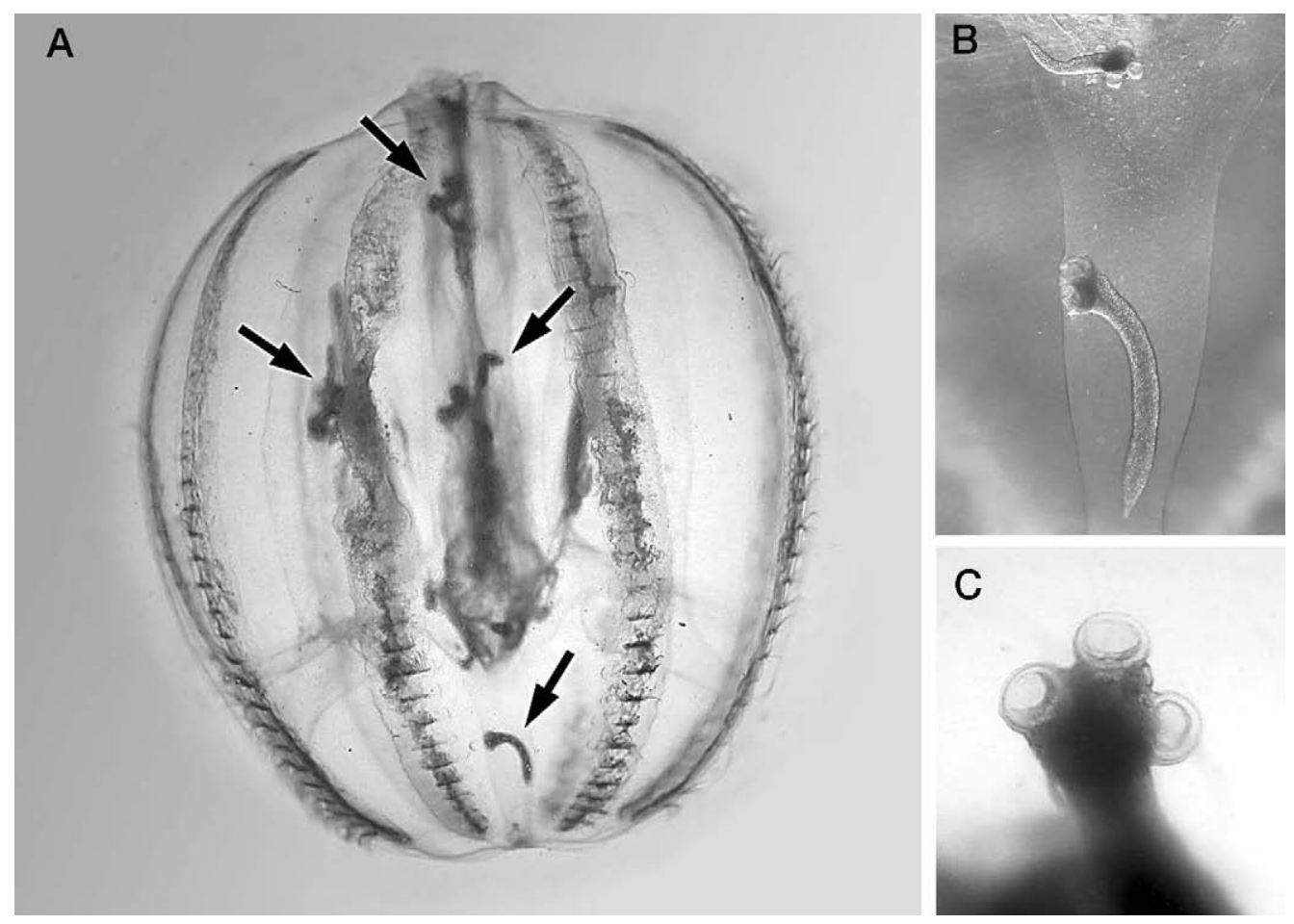

FIG. 9. - Pleurobrachia pileus: A, specimen $20 \mathrm{~mm}$ in oral-aboral length with 6 cestodes marked by arrows. B, two cestodes located in the canal of the infundibulum, the longest is $2.4 \mathrm{~mm}$. C, detail of the four suckers of the cestode head.

Phylum CTENOPHORA Eschscholtz, 1829,

Class TenTACUlata Eschscholtz, 1825

Order CYDIPPIDA Gegenbaur, 1856

Family PleurobrachidAe Chun, 1880

Pleurobrachia pileus (O.F. Müller, 1776)

(Fig. 9A-C)

Material and remarks: In 2003, many specimens (1.5 to $2.0 \mathrm{~cm}$ in oral-aboral length) were collected in the top $35 \mathrm{~m}$ of Georges Basin waters. Some of them were parasitized by cestodes (1.6-2.4 $\mathrm{mm}$ in length) ranging from 1 to 6 per ctenophore (Fig. 9 A-C). The cestodes were located in the canal of the infundibulum, the pharynx or the tentacle sheath of the ctenophores. This association was reported off Woods Hole by van Cleave (1927) who found four immature cestodes $(1.5 \mathrm{~mm}$ in length, preliminarily identified as Scolex polymorphus by Edwin Linton) in three collected specimens of Pleurobrachia pileus, but no further observations were noted. We could not identify the cestode species. It is known that the names Scolex polymorphus and S. pleuronectis, both of which have already been found in ctenophores, encompass several cestode genera (Stunkard, 1977, p. 402 for an updating). Ctenophores are sometimes the main prey of fishes (e.g. Mianzan et al., 1996) and play a role as intermediate hosts in the life-cycle of cestodes. However, cestodes are difficult to identify and a life cycle involving coelenterates has not been established yet (Lauckner, 1980; Purcell and Arai, 2001). Specimens of Pleurobrachia were not collected in 2002 but several were found in Georges Basin in 2004.

\author{
Class NudA Chun, 1879 \\ Order BEROIDA Eschscholtz, 1829 \\ Family BEROIDAE Eschscholtz, 1829? \\ Beroe sp. (Figs. 7J and 10)
}

Material: Few specimens were collected in the first cruise (Oceanographer Canyon, 5 September 2002, 778-680 m, 1 specimen; 22 September 2002, 680-583 m depth, 1 specimen; $679 \mathrm{~m}$ depth, 2 specimens. Hydrographer Canyon, 17 September 2002, 600 to $500 \mathrm{~m}$ depth, 4 specimens). In 2003 , it was common and widely distributed in the basins (Wilkinson, top $110 \mathrm{~m}$ depth; Georges, top $210 \mathrm{~m}$ depth) with some individuals reaching $21 \mathrm{~cm}$ in oral-aboral length. In 2004, it was often observed in surface waters and several specimens were captured by the Meternet hauls in Wilkinson and Georges basins but not in the canyons.

Remarks: The specimens have not been identified to species level following the recommendations of a genus review stated by Mills et al. (1996). The Meternet haul that collected the two new anthomedusae species also captured three small transparent Beroe and a large pinkish one. The large specimen $(8 \mathrm{~cm}$ in oral-aboral length) was para- 


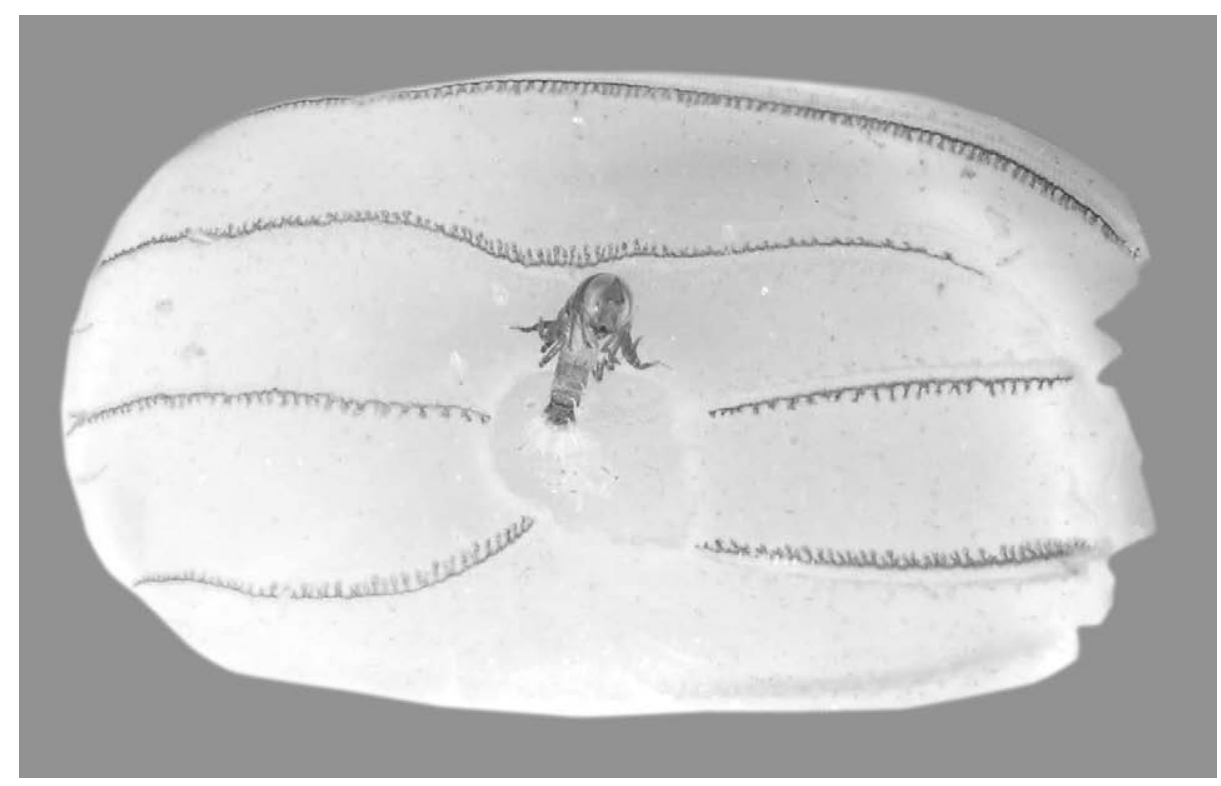

FIG. 10. - Beroe sp. with an amphipod Hyperia galba (identified by Rebeca Gasca) preying on it. The oral side was wrenched by a molecular parasite.

sitized by a large, brown specimen of the hyperid amphipod Hyperia galba that preyed upon the surface tissues through which it had made a hole $(1 \mathrm{~cm}$ in diameter, Fig. 10). The Beroe was placed in a bowl and the hyperid remained attached to it, devouring the hole edges.

\section{CONCLUSIONS}

This study reveals that the gelatinous fauna in the Gulf of Maine comprise several species about which little is known or which have not yet been described. Siphonophores appear to have a high species richness (33 of the 160 species described to date in world oceans), while hydroidomedusae is proportionally the less rich taxon (26 of approx. 842 species described worldwide, see Bouillon and Boero, 2000). The scyphomedusae collected were almost the same species reported by Larson et al. (1988). The number of mollusc and salp species was low. A comparison with the gelatinous species occurring in the Gulf of Maine and discussed by Bigelow (1926) shows some species that occur in both studies (Nanomia cara, Physophora hydrostatica, Melicertum octocostatum, Clytia hemisphaerica, Phacellophora camstchatica, Periphylla periphylla, Beroe sp., Pleurobrachia pileus) but most of the rest of the species do not.

These results encourage the exploration of the gelatinous plankton populations in the Gulf of
Maine and the rest of the world's oceans because many species and biological relationships remain unknown.

\section{ACKNOWLEDGEMENTS}

The scientific results of this study and the publication have been funded by the Belgian Fonds Léopold III pour l'Exploration et la Conservation de la Nature. We thank the captains and crew of the Seward Johnson vessels for assisting with all aspects of animal collection. The Institut Royal des Sciences Naturelles de Belgique is acknowledged for the loan of biological material deposited there. The Japanese Society for Promotion of Science supported FP in a part of this study. This research was supported by grants to MY from the National Science Foundation (OCE 0002493) and the Harbor Branch Oceanographic Institution. This study has been conducted in the frame of the Census of Marine Zooplankton project. We thank two anonymous referees by their useful comments. Harbor Branch Oceanographic Institution Contribution No. 1637.

\section{REFERENCES}

Agassiz, A. - 1865. Illustrated catalogue of the Museum Comparative Zoology at Harvard College, No 2. North American Acalephae: 1-234.

Bigelow, H.B. - 1909. Medusae. Rep. Sci. Res. Exped. Eastern Tropical Pacific U.S. Fish Comm. "St. Albatross” 1904-1905. 
XVI. Mem Mus Comp. Zool Harvard, 37: 1-243.

Bigelow, H.B. - 1914. Fauna of New England.12. List of the medusae craspedotae, siphonophorae, scyphomedusae, ctenophorae. Occ. Pap. Bost. Soc. Nat. Hist., 7: 1-38.

Bigelow, H.B. - 1926. Plankton of the offshore waters of the Gulf of Maine. Bull. Bur. Fish., 60: 1-509.

Boero, F., J. Bouillon and C. Gravili. - 2000. A survey of Zanclea, Halocoryne and Zanclella (Cnidaria, Hydrozoa, Anthomedusae, Zancleidae) with description of new species. Ital. J. Zool., 67: 93-124.

Bouillon, J. - 1978. Hydroméduses de la mer de Bismarck (Papouasie, Nouvelle-Guinée). I.- Anthomedusae Capitata (Hydrozoa-Cnidaria). Cah. Biol. Mar., 19: 249-297.

Bouillon, J. - 1984a. Révision de la famille des Phialucidae (Kramp 1955) (Leptomedusae, Hydrozoa, Cnidaria), avec un essai de classification des Thecatae-Leptomedusae. Indo-Malayan Zool., 1: 1-24.

Bouillon, J. - 1984b. Hydroméduses de la Mer de Bismarck (Papouasie Nouvelle-Guinée). Partie IV. Leptomedusae (Hydrozoa-Cnidaria). Indo-Malayan Zool., 1: 25-113.

Bouillon, J. - 1985. Essai de classification des HydropolypesHydroméduses (Hydrozoa-Cnidaria). Indo-Malayan Zool., 2: 29-243.

Bouillon, J. - 1995. Hydromedusae of the New Zealand Oceanographic Institute (Hydrozoa, Cnidaria). N. Z. J. Zool., 22: $223-238$

Bouillon, J. and F, Boero. - 2000. Synopsis of the families and genera of the hydromedusae of the world, with a list of the worldwide species. Thal. Sal., 24: 47-296.

Bouillon, J., M.D. Medel, F. Pagès, J.M. Gili, F. Boero and C. Gravili. - 2004. Fauna of the Mediterranean Hydrozoa. Sci. Mar., 68 (Suppl. 2): 1-449.

Brinckmann-Voss, A. and M.N. Arai. - 1998. Further notes on Leptolida (Hydrozoa:Cnidaria) from Canadian Pacific waters. Zool. Verh., 323: 37-68.

Brooks, W.K. - 1903. On a new genus of hydroid jelly-fishes. Proc. Am. Phil. Soc., 42: 11-14.

Cairns, S.D, D.R. Calder, A. Brinckmann-Voss, C.B. Castro, D.G Fautin, P.R. Pugh, C.E. Mills, W.C. Jaap., M.N. Arai, S.H.D. Haddock and D.M. Opresko. - 2002. Common and scientific names of aquatic invertebartes from the United States and Canada: Cnidaria and Ctenophora, second edition 2002. Am. Fish. Soc. Spec. Publ., 28: 1-115.

Calder, D.R. - 1991. Shallow-water hydroids of Bermuda: the thecatae, exclusive of Plumularioidea. Life Sci. Contr., 154: 1-140.

Cleave, H.J. van. - 1927. Ctenophores as the host of a cestode. Trans. Am. Micr. Soc., 46: 214-215.

Edwards, C. -1963 . On the anthomedusae Tiaranna rotunda and Modeeria formosa. J. mar. biol. Ass. U.K., 43: 457-467.

Edwards, C - 1966. The hydroid and the medusa Bougainvillia principis, and a review of the British species of Bougainvillia. J. mar. biol. Ass. U.K., 46: 129-152.

Edwards, C - 1973. The medusa Modeeria rotunda and its hydroid Stegopoma fastigiatum, with a review of Stegopoma and Stegolaria. J. mar. biol. Ass. U.K., 53: 573-600.

Fewkes, J.W. - 1888. On certain medusae from New England. Bull. Mus. Comp. Zool. Harv. Univ., 13: 209-240.

Flag, C.N. - 1987. Hydrographic structure and variability. In: R.H. Backus and D.W. Bourne (eds.) Georges Bank, pp. 108-124. Coastal Research Center, Woods Hole Oceanographic Institution, Woods Hole.

Hartlaub, C. - 1917. Nordisches Plankton,Craspedoten Medusen, XII , I, 4: 411-414.
Kramp, P.L. - 1942. Medusae. The Godthaab Expedition 1928. Meddr.. Grønland. 81: 1-168.

Kramp, P.L. - 1959. Hydromedusae of the Atlantic Ocean and adjacent waters. Dana Rep., 46: 1-283.

Larson, R.J., G.R. Richardson, P.R. Pugh, J.A. Janssen, R.H. Gibbs, J.E. Craddock, C.E. Mills, R.L. Miller and R.W. Gilmer. 1988. Midwater community studies off New England using the Johnson Sea-Link submersibles. NOAA Nat. Und. Res. Prog, Res. Rep., 88-4: 265-281.

Lauckner, G. - 1980. Diseases of Ctenophora. In: O. Kinne, (ed.) Diseases of marine animals. Vol. 1. General aspects. Protozoa to Gastropoda, pp. 239-253. John Wiley \& Sons.

Mayer, A.G. - 1912. Ctenophores of the Atlantic coast of North America. Carnegie Institution, Washington: 1-58.

Mianzan, H.W., N. Mari, B. Prenski and F. Sánchez, - 1996. Fish predation on neritic ctenophores from the Argentine continental shelf: A neglected food resource?. Fish. Res., 27: 69-79.

Mills, C.E., P.R. Pugh, G.R. Harbison and S.H.D. Haddock. - 1996. Medusae, siphonophores and ctenophores of the Alborán Sea, south-western Mediterranean. Sci. Mar., 60: 145-163.

Pagès, F., J.M. Gili and J. Bouillon. - 1992. Medusae (Hydrozoa, Scyphozoa, Cubozoa) of the Benguela Current (south-western Atlantic). Sci. Mar. 56(Suppl. 1): 1-64.

Pagès, F. and C. Orejas. - 1999. Medusae, siphonophores and ctenophores of the Magellan region. Sci. Mar., 63(Suppl. 1): 51-57.

Pugh, P.R. and F. Pagès. - 1995. Is Lensia reticulata a diphyine species (Siphonophorae, Calycophora, Diphyidae)? A redescription. Sci. Mar., 59: 181-192.

Purcell, J.E. and M.N. Arai. - 2001. Interactions of pelagic cnidarians and ctenophores with fish: a review. Hydrobiologia, 451: $27-44$.

Ranson, G. - 1936. Méduses provenant des Campagnes du Prince Albert I de Monaco. Rés. Camp. Scient. Monaco, 92: 1-245.

Russell, F.R.S. - 1953. The medusae of the British Isles. Cambridge University Press, Cambridge.

Schuchert, P. - 1996. The marine fauna of New Zealand: athecate hydroids and their medusae (Cnidaria: Hydrozoa). N.Z. Oceanogr. Inst. Mem.,106: 1-159.

Shih, C.-T., A.J.G. Figueira and E.H. Grainger. - 1971. A synopsis of Canadian marine zooplankton. Bull. Fish. Res. Bd. Can., 176: $1-264$.

Stunkard, HW. - 1977. Studies on tetraphyllidean and tetrarhynchidean metacestodes from squids taken on the New England coast. Biol Bull., 153: 387-412.

Totton, A.K. - 1965. A Synopsis of the Siphonophora. British Museum of Natural History. $230 \mathrm{pp}$.

Vanucci, M. and W.J. Rees. - 1961. A revision of the genus Bougainvillia (Anthomedusae). Bol. Inst. Oceanogr. Sao Paulo, 9: 57-100.

Wrobel, D. and C.E. Mills. - 1998. Pacific Coast Pelagic Invertebrates-A Guide to the Common Gelatinous Animals. Sea Challengers and the Monterey Bay Aquarium, Monterey, California: $1-108$

Xu, Z. and J. Zhang. - 1978. On the hydromedusae, siphonophores and scyphomedusae from the coast of the east Guandong province and south Fujian province, China. Acta Sci. Nat. Univ. Amoien., 17: 19-63.

Scient. ed.: P. Abelló

Received April 1, 2005. Accepted March 13, 2006

Published online July 5, 2006. 
